IRA-International Journal of Education \& Multidisciplinary Studies ISSN 2455-2526; Vol.06, Issue 03 (2017)

Pg. no. 231-240

Institute of Research Advances https://research-advances.org/index.php/IJEMS

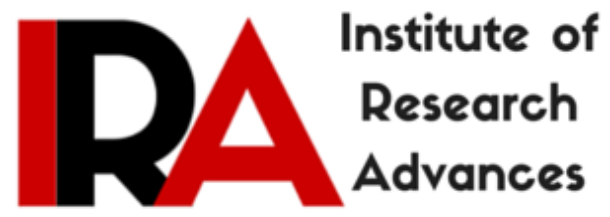

\title{
A Sociological Study of Health Consciousness among the Senior Citizens: With Special Reference to Radhey Green Colony of Dayalbagh Area of Agra City
}

\author{
Dr. Birpal Singh Thenua \\ Assistant Professor (Sociology) \\ Department of Sociology \& Political Science \\ Faculty of Social Sciences \\ Dayalbagh Educational Institute (Deemed University) \\ Dayalbagh, Agra - 5, India.
}

Type of Review: Peer Reviewed.

DOI: http://dx.doi.org/10.21013/jems.v6.n3.p3

\section{How to cite this paper:}

Thenua, B. (2017). A Sociological Study of Health Consciousness among the Senior Citizens: With Special Reference to Radhey Green Colony of Dayalbagh Area of Agra City. IRA International Journal of Education and Multidisciplinary Studies (ISSN 2455-2526), 6(3), 231240. doi:http://dx.doi.org/10.21013/jems.v6.n3.p3

(C) Institute of Research Advances

\section{(cc) EY-NC}

This work is licensed under a Creative Commons Attribution-Non Commercial 4.0 International License subject to proper citation to the publication source of the work.

Disclaimer: The scholarly papers as reviewed and published by the Institute of Research Advances (IRA) are the views and opinions of their respective authors and are not the views or opinions of the IRA. The IRA disclaims of any harm or loss caused due to the published content to any party. 


\section{ABSTRACT}

Health is one of the most important assets of human being and can be viewed as prerequisite for individual and national development. It is popular saying in Indian Society since ancient times 'Health is the wealth'. It is true even today. The expansion of Yoga, meditation and modern health technology through mass-media, people are being more and more aware toward their health. Our government is also aware for wellbeing of health of our every individual including senior citizens. Senior citizens are the assets and heritage of our society as they have a long experience of socio-economic, cultural and environment issues. Society cares their health and lives and makes them conscious towards their health. Their health depends on their consciousness. But the health consciousness among senior citizens is a complex phenomenon and heterogeneous process determined by a number of physical, emotional, biological and socio-cultural factors. It is a subjective mental attention toward one's health, hygiene and environment.

Key words: Consciousness, Yoga, Vyaayam, Meditation, Medical Checkup, Life Style, Social Environment, Human Biology, Toxins

\section{INTRODUCTION}

Today's lifestyle is certainly more complicated than that of 50 years ago. Nowadays, people have been able to balance their work schedule vis-s-vis their cherished private moments. The trend towards better health and the resulting longer life expectancy has reshaped peoples' ideas of old age. With the advances in diagnosing and treating illness and by practicing a healthy lifestyle, people can increase both their quality life and their anticipated life expectancy (Gesite 2015). Health is a physical and mental wellbeing condition of an individual. It can be viewed as a prerequisite for both individual (human) and national development (Berry, Dalal \& Pande 1994). It is determined by a number of factors such as human biology and social environment (Paterson \& Feightner 1997). Human biology includes individual organism and social environment includes education, literacy, income, and shelter. The physical environment includes exposure of toxins, occupational and other hazards. The life styles of the individuals take in nutrition, substance abuse, and sexual practice, use of protective devices, physical activities and fitness. A small portion of health of an individual is determined by the medical care and effective portion of the health is determined by social practices and behavior and life styles. Health consciousness among senior citizens is a complex phenomenon and a number of physical, emotional, biological and socio-cultural factors are involved in it. Health among the senior citizens is a serious issue because of their age. At this stage most of the parts of body loss their functions and body became mentally and physically weakened. Therefore, it is very difficult to objectively evaluate the health consciousness among senior citizens. Health is a state of complete physical, mental and social wellbeing, and not merely the absence of disease and infirmity. The concept of health was understood in a new light to mean a highly subjective experience or a mental representation guiding responses to symptoms and various kinds of health threats (Babao and Mosacoso 2008).

World community is aware towards health of senior citizens. In the Alma Ata Declaration of Health for All by the year 2000 (WHO1978) and in the Ottawa Charter (WHO 1988) international community took the concern of health of all. The concern of health of the senior citizens at the U.N.O. in 1948 and in 1982 the U. N. General Assembly endorsed the International Plan of Action on Senior Citizens (aging). In 1990, the assembly designated October Ist as the International Day for the Elderly (Senior Citizens), later renamed as the 'International Day of Elder Persons. The United Nations General 
Assembly decided in 1992 to observe the International Year of Older Persons in 1999 to raise awareness of the fast changing demographic picture of older persons. But the Indian official delegation to the World Assembly at Vienna stated that our country did not have much of a problem of the aged since the traditional family took care of the older members and the government health services took care of their health needs (Karkal 1999). But in $21^{\text {st }}$ century the picture has been changed. The World Health Report of 2008, describe a return to primary health care to address that health progressed remarkably over the past three decades. On average people are now living seven year longer (Gesite 2015). The population of senior citizens is increasing and the attention of family on them is decreasing.

In 1947 the population over sixty years was just $5.5 \%$ in total population of India where as life expectancy was 31 years (Sivaramakrishnan 2014). The early population in the world which was 205 million in 1950 is expected to reach one billion by 2020; $70 \%$ of that will be in developing countries including India (Shah 2015). In 2001 in India the population of aged was $7.70 \%$ in total population with increasing life expectancy and medical facilities.

\begin{tabular}{|l|l|l|l|l|}
\hline \multicolumn{5}{|c|}{ Percentage of Aged (60+) in Indian Population } \\
\hline $\begin{array}{l}\text { S. } \\
\text { No. }\end{array}$ & Year & $\begin{array}{l}\text { Percentage of } \\
\text { Aged } \\
\text { population }\end{array}$ & $\begin{array}{l}\text { Number of Aged ( } \\
\text { in million) }\end{array}$ & $\begin{array}{l}\text { Decadal Percent } \\
\text { Change }\end{array}$ \\
\hline 1 & 1951 & 5.43 & 19.61 & 13.31 \\
\hline 2 & 1961 & 5.53 & 24.71 & 21.51 \\
\hline 3 & 1971 & 5.97 & 32.70 & 24.80 \\
\hline 4 & 1981 & 6.42 & 43.98 & 24.66 \\
\hline 5 & 1991 & 6.55 & 55.30 & 23.16 \\
\hline 6 & 2001 & 7.70 & 75.93 & 16.10 \\
\hline
\end{tabular}

Source: Registrar General of India, Census of Respective Years

Consciousness: Consciousness is a subjective awareness of mental events. Consciousness depends on the attention of an individual. Attention is the focusing of the consciousness by providing heightened sensitivity to a certain stimuli in awareness. One of the roles of consciousness seems to be the monitor the self and the environment, and control our thought, behavior and activities. Consciousness has a number of levels: the sub-conscious, the conscious and the super consciousness. The level of consciousness represented different degrees of intensity of awareness. Natsoulas defined consciousness as awake, consciousness means being aware of any thing- external object or mental occurrences. It refers to the totality of the impressions, thoughts, and feelings which make up the person's conscious being; perceiving the whole set of one's mental episodes. It is tempting to suggest that "consciousness" constitutes (private) meta-self awareness, because there is a perception of the totality, the whole set, and the perception is of internal events (impressions, thoughts, feelings) (Natsoulas 1997 b, 1998).

Health Consciousness: Health consciousness is a subjective awareness about one's health and physical and mental wellbeing. It is a state of one's own attention on his health. It occurs when an individual focuses not on the external environment but the internal milieu. Health consciousness among the senior citizens is a complex issue. It is a heightened awareness and sensitivity among the senior citizens not only about their physical and mental wellbeing but also about their environment, lifestyle and their behavior. Senior people usually express high levels of satisfaction and quality of life, even though they may be facing comorbidities and disabilities (Lima, Silva \& Galhardoni 2008). 
Health consciousness is a self awareness about someone's health, i.e. a self evaluation of someone's functional state. Self awareness is the result of physical and mental impairments related to aging and it is associated with environmental factors (Freitas et al. 2006). In the words of Basu and Dutta an individual's level of health consciousness is closely related to how he or she seeks and responds to health information (Basu \& Dutta 2008). Individual's health consciousness is their orientation toward a wellness of lifestyle (Kraft \& Fodeel 1993). It is solely a psychological and inner status of a person, including health alertness, health self consciousness, health involvement and self monitoring of one's health (Gould 1998). In the words of Iversen and Kraft defined health consciousness as the tendency to focus attention on one's health (Iversen and Kraft 2006). According to Furnham and Forey health consciousness as one's ecological and self awareness of lifestyle- including health information seeking, food consumption, concern for the natural environment and perception of prescription drugs (Furnham \& Forey 1994). On the basis of above descriptions of health consciousness we can say that health consciousness includes (i) integration of health behavior, (ii) attention of one's health, (iii) health information and seeking and usages, (iv) personal health responsibility, and (v) health motivation. Ageing is both complex and heterogeneous process due to several physical, emotional and social factors. Therefore, it is difficult to objectively evaluate the health of senior citizens (Banhato et al. 2015).

\section{RESEARCH QUESTIONS:}

The research questions of the study are as follows-

$>$ What is the socio-economic background of senior citizens living in Radhey Green Colony of Dayalbagh area of Agra city?

$>$ What is their life style of senior citizens living in Radhey Green Colony of Dayalbagh area of Agra city?

$>$ What is the health attention of senior citizens living in Radhey Green Colony of Dayalbagh area of Agra city?

$>$ What is the health awareness among the senior citizens living in Radhey Green Colony of Dayalbagh area of Agra city?

\section{DESIGNE OF THE STUDY:}

The researcher has adopted descriptive research design to describe the health consciousness among the senior citizens. In the given study efforts have been made to describe the causal relationship with consciousness and mental and physical well being of senior citizens.

\section{AREA OF THE STUDY:}

The area of the research is Radhey Green Colony of Dayalbagh area of Agra City of Uttar Pradesh. Dayalbagh area of Agra is known for spirituality, education, greenery and eco-friendly. This is the pollution free area of Agra. In solar energy Dayalbagh has second place in Uttar Prades. In Radhdy Green Colony campus there are three colony- Radhey Green, Shree Radhey Greens and P. P. Garden. There are 120 families residing in the colony campus. All the residents of this colony are of middle / upper middle class. 


\section{UNIVERSE OF THE STUDY:}

The universe of the research is consisted of all the senior citizens (male and female) of both genders of Radhey Green Colony of Dayalbagh area. The number of male senior citizens is 15 and female senior citizens are 13.

\section{UNIT OF THE STUDY:}

The unit of the study is the senior citizen of Radhey Green colony campus of Dayalbagh area of Agra City.

\section{CENSUS METHOD:}

After consideration of total number of units the research, the researcher has decided to use census method for the collection of necessary information through fieldwork.

\section{TOOL OF DATA COLLECTION:}

For the collection of required information which was needed for research questions, a structured interview-schedule was prepared. This interview-schedule was divided into tow parts, first part was related with the questions of socio-economic and familial background of the senior citizens and the second part of the interview-schedule was concerned with the questions of health consciousness.

\section{DATA COLLECTION:}

In the present study, both types of data have been used. Primary data were collected from the respondents (senior citizens) with the help of structured interview-schedule. For the collection of primary information in the months of September and October 2016, fieldwork was carried on. Secondary data were collected from the different books, journals, news papers and other documents.

\section{FINDINGS OF THE STUDY:}

The major findings of the study derived from the primary data collection through interview schedule (field work) from the senior citizens are as follows:

TABLE: I

GENERAL INFORMATION OF SENIOR CITIZENS

\begin{tabular}{|c|c|c|c|c|c|c|c|}
\hline \multicolumn{4}{|c|}{ Age of the Senior Citizens } & \multicolumn{4}{|c|}{ Education of the Senior Citizens } \\
\hline S. No. & Age & Frequency & $\%$ & S. No. & Education & Frequency & $\%$ \\
\hline 1 & $60-65$ & 15 & 53.27 & 1 & High School & 2 & 7.14 \\
\hline 2 & $65-70$ & 6 & 21.42 & 2 & Intermediate & 18 & 64.28 \\
\hline 3 & $70-75$ & 4 & 14.28 & 3 & Graduate & 7 & 25.00 \\
\hline 4 & 75- above & 3 & 10.71 & 4 & $\begin{array}{l}\text { PG/ } \\
\text { Professional }\end{array}$ & 1 & 3.57 \\
\hline 5 & Total & 28 & 100.00 & 5 & Total & 28 & 100.00 \\
\hline \multicolumn{4}{|c|}{ Caste Category of the Senior Citizens } & \multicolumn{4}{|c|}{ Family Structure of the Senior Citizens } \\
\hline S. No. & $\begin{array}{l}\text { Caste } \\
\text { Category }\end{array}$ & Frequency & $\%$ & S. No. & Family Type & Frequency & $\%$ \\
\hline 1 & General & 20 & 71.42 & 1 & Joint Family & 21 & 75.00 \\
\hline
\end{tabular}


IRA-International Journal of Education \& Multidisciplinary Studies

\begin{tabular}{|c|l|c|c|c|l|c|c|}
\hline 2 & O.B.C. & 7 & 25.00 & 2 & Nuclear Family & 7 & 25.00 \\
\hline 3 & S.C. & 1 & 3.57 & 3 & $\begin{array}{l}\text { Extended } \\
\text { Family }\end{array}$ & - & - \\
\hline 4 & S.T. / Others & - & - & & - & - & - \\
\hline 5 & Total & 28 & 28 & & \multicolumn{7}{|c|}{ Total } & 28 & 100.00 \\
\hline \multicolumn{7}{|l|}{ Marital Status of Senior Citizens } & \multicolumn{5}{|c|}{ Occupation do /did } \\
\hline S. No. & Marital Status & Frequency & $\%$ & S. No. & Occupation & Frequency & $\%$ \\
\hline 1 & Married & 21 & 75.00 & 1 & Govt. Service & 20 & 71.42 \\
\hline 2 & Unmarried & 1 & & 2 & Pvt. Service & 5 & 17.85 \\
\hline 3 & Separated & 1 & 3.57 & 3 & $\begin{array}{l}\text { Self } \\
\text { Employment }\end{array}$ & 2 & 7.14 \\
\hline 4 & Widower & 5 & 17.85 & 4 & Others & 1 & 3.57 \\
\hline 6 & Total & 28 & 100.00 & 6 & Total & 28 & 100.00 \\
\hline
\end{tabular}

It is clear from the above table that more than half of the respondents are of 60-65 years of age and one-fifth of them are 65-70 years old. Only 14.28 of the respondents belong to the category of 70-75 years age and rest $(10.71 \%)$ are more than 75 years old. If we consider the education of senior citizens most $(64.28 \%)$ of the respondents are intermediate passed and only $25.00 \%$ are graduate. $7.14 \%$ are High school passed and rest is P. G. or professional degree holder. The caste category of the senior citizens, $71.42 \%$ are of General caste category, $25.00 \%$ from OBC category and rest (3.57\%) are of S.C. caste category. If we talk about the family structure of the senior citizens, three-fourth $(75.00 \%)$ of them are living in joint family and rest $(25.00 \%)$ are living in nuclear family. $75.00 \%$ of the respondents responded that their marital status is married, $17.95 \%$ are widowers / widows and rest (3.57\%) are separated. The occupation they did or doing, $71.42 \%$ of the respondents replied that they did government services, $17.85 \%$ did private services and rest $(10.72 \%)$ had self and other types of employments.

TABLE: II

FINANCIAL INFORMATION

\begin{tabular}{|c|c|c|c|c|l|c|c|}
\hline \multicolumn{4}{|c|}{ Personal Income in Rupees (monthly) } & \multicolumn{3}{c|}{ Family Income from all Sources Including Respondent in } \\
Rupees (monthly)
\end{tabular}

The financial condition of the senior citizens, $42.85 \%$ of them responded that their monthly personal income is Rs. 10000-150000, one-third (32.14\%) of them have Rs. 5000-10000, $14.28 \%$ have upto Rs.5000 and rest 10.71 have more than Rs. 15000 monthly personal income. In regard to the family income of the senior citizens, $32.14 \%$ of them said that their monthly family income from all sources is Rs. 20000-30000, one-fourth (25.00\%) have Rs. 10000-20000, and 21.42\% said that their monthly family 
income upto Rs. 10000. In the category of Rs. 30000-40000 monthly income and more than Rs.40000 were $10.71 \%, 10.71 \%$ respectively.

TABLE: III

LIFE STYLE \&HEALTH CONSCIOUSNESS AMONG THE SENIOR CITIZENS

\begin{tabular}{|c|c|c|c|c|c|c|c|}
\hline \multicolumn{4}{|c|}{ Wake Up Time in the Morning } & \multicolumn{4}{|c|}{ Physical Exercise Excluding Walking } \\
\hline S. No. & Wakeup Time & Frequency & $\%$ & S. No. & Exercise & Frequency & $\%$ \\
\hline 1 & 4 O' clock & 18 & 64.28 & 1 & Regular & 22 & 78.57 \\
\hline 2 & 5 O’ clock & 4 & 14.28 & 2 & Occasional & 4 & 14.28 \\
\hline 3 & 6 O' clock & 3 & 11.71 & 3 & Never & 2 & 7.14 \\
\hline 4 & 7 O’ clock & 2 & 7.14 & 4 & - & - & - \\
\hline 5 & $8 \mathrm{O}$, clock & 1 & 3.57 & 5 & - & - & - \\
\hline 6 & Total & 28 & 100 & 6 & Total & 28 & 100 \\
\hline \multicolumn{4}{|c|}{ Morning or Evening Walk } & \multicolumn{4}{|c|}{ Walk in km } \\
\hline S. No. & Morning Walk & Frequency & $\%$ & S. No. & Walk in $\mathrm{km}$ & Frequency & $\%$ \\
\hline 1 & Regular & 18 & 64.28 & 1 & 4 & 14 & 50.00 \\
\hline 2 & Occasional & 6 & 21.42 & 2 & 3 & 8 & 28.57 \\
\hline 3 & Never & 4 & 14.28 & 3 & 2 or 1 & 2 & 7.14 \\
\hline 4 & - & - & - & 4 & N.A. & 4 & 14.28 \\
\hline 6 & Total & 28 & 100 & 6 & Total & 28 & 100.00 \\
\hline \multicolumn{4}{|c|}{ Meditation } & \multicolumn{4}{|c|}{ Yoga } \\
\hline S. No. & Meditation & Frequency & $\%$ & S. No. & Breakfast & Frequency & $\%$ \\
\hline 1 & Regular & 20 & 71.42 & 1 & Regular & 22 & 78.57 \\
\hline 2 & Occasional & 6 & 21.42 & 2 & Occasional & 6 & 21.42 \\
\hline 3 & Never & 2 & 7.14 & 3 & Never & 2 & 7.14 \\
\hline 4 & - & - & - & 4 & - & - & - \\
\hline 5 & - & - & - & 5 & - & - & - \\
\hline 6 & Total & 28 & 100 & 6 & Total & 28 & 100.00 \\
\hline \multicolumn{4}{|c|}{ Health Examination } & \multicolumn{4}{|c|}{ Physical Checkup } \\
\hline S. No. & $\begin{array}{l}\text { Health } \\
\text { Examination }\end{array}$ & Frequency & $\%$ & S. No. & $\begin{array}{l}\text { Physical } \\
\text { Checkup }\end{array}$ & Frequency & $\%$ \\
\hline 1 & Regular & 25 & 89.28 & 1 & Regular & 25 & 89.28 \\
\hline 2 & Occasional & 2 & 11.71 & 2 & Occasional & 2 & 7.14 \\
\hline 3 & Never & - & - & 3 & Never & 1 & 3.57 \\
\hline 4 & - & - & - & 4 & - & - & - \\
\hline 5 & - & - & - & 5 & - & - & - \\
\hline 6 & Total & 28 & 100.00 & 6 & Total & 28 & 100.00 \\
\hline \multicolumn{4}{|c|}{ Substance Abuse } & \multicolumn{4}{|c|}{ Types of Substance Abuse *included } \\
\hline S. No. & Substance Abuse & Frequency & $\%$ & S. No. & $\begin{array}{l}\text { Types of } \\
\text { Substance }\end{array}$ & Frequency & $\%$ \\
\hline 1 & Regular & 4 & 14.28 & 1 & Alcohol & 8 & 28.57 \\
\hline 2 & Occasional & 6 & 21.42 & 2 & Drugs & 2 & 7.14 \\
\hline 3 & Never & 18 & 64.28 & 3 & Bhang & 1 & 3.57 \\
\hline 4 & - & - & - & 4 & N.A. & 18 & 64.28 \\
\hline 5 & Total & 28 & 100.00 & 5 & Total & - & - \\
\hline \multicolumn{4}{|c|}{ Awareness towards their Meal } & \multicolumn{4}{|c|}{$\begin{array}{l}\text { Safety Measures Used by Senior Citizens } \\
\text { *Included }\end{array}$} \\
\hline S. No. & Reaction & Frequency & $\%$ & S. No. & Safety Measures & Frequency & $\%$ \\
\hline
\end{tabular}


IRA-International Journal of Education \& Multidisciplinary Studies

\begin{tabular}{|c|l|c|c|c|l|c|c|}
\hline 1 & Full Aware & 18 & 64.28 & 1 & Helmets & 20 & 71.42 \\
\hline 2 & Average & 6 & 21.42 & 2 & Seat Belt & 22 & 78.57 \\
\hline 3 & Less Aware & 4 & 14.28 & 3 & Lathi / Stick & 8 & 28.57 \\
\hline 4 & - & - & - & 4 & Knee Guard & 5 & 17.85 \\
\hline 5 & Total & 28 & 100.00 & 5 & Total & - & - \\
\hline \multicolumn{7}{|l|}{ Where their Physical Health Stand? } & \multicolumn{1}{|l|}{ Where their Mental Health Stand? } \\
\hline S. No. & Reaction & Frequency & $\%$ & S. No. & Reaction & Frequency & $\%$ \\
\hline 1 & Very Good & 12 & 42.85 & 1 & Very Good & 13 & 46.42 \\
\hline 2 & Good & 6 & 21.42 & 2 & Good & 6 & 21.42 \\
\hline 3 & Average & 5 & 17.85 & 3 & Average & 5 & 17.85 \\
\hline 4 & Poor & 3 & 11.71 & 4 & Poor & 2 & 7.14 \\
\hline 5 & Very Poor & 2 & 7.14 & 5 & Very Poor & 2 & 7.14 \\
\hline 6 & Total & 28 & 100.00 & 6 & Total & 28 & 100.00 \\
\hline
\end{tabular}

Regarding the lifestyle and health consciousness of the senior citizens, $64.28 \%$ of the respondents wake up at 4 O' clock early in the morning, $14.28 \%$ wake up at 5 O'clock, $11.71 \%$ at 6 O' clock, $7.14 \%$ at $7 \mathrm{O}^{\prime}$ clock and rest of the respondents $(3.57 \%)$ wake up at $8 \mathrm{O}^{\prime}$ clock in the morning. Slightly more than three-fourth of the respondents $(78.57 \%)$ do regular physical exercises, $14.28 \%$ occasional and rest (7.14\%) said that they never did because of poor health and doctor's advice. $64.28 \%$ of the respondents do morning walk regular, $21.42 \%$ occasional and rest (14.28\% of the respondents never did morning or evening walk. The distance they walk, half of the respondents said that they walk around $4 \mathrm{KM}$. daily, $28.57 \% 3 \mathrm{KM}$ and $7.14 \% 1-2 \mathrm{KM}$.

Regarding meditation, slightly less than three-forth (71.42\%) of the respondents do meditation regular while slightly less than one-forth $(21.42 \%)$ of the respondents do occasional and rest $(7.14 \%)$ never do meditation. $78.57 \%$ of senior citizens responded that they do regular Yoga, $21.42 \%$ do occasional and rest (7.14\%) never do Yoga. Health examination from the doctor, $89.28 \%$ of the respondents said that they go to doctor for health examination regular and rest (11.71\%) said that they go occasional for health examination to the doctor. Regarding the physical check up form the physician and physiotherapist, $89.28 \%$ of the respondents said that they regular go to the physical check up, $7.14 \%$ occasional and rest (3.57\%) never go to physical check up. Regarding substances used by senior citizens, $14.28 \%$ of the respondents said that they take substances regular, $21.42 \%$ occasional and rest $64.28 \%$ responded that they never use any kind of substance. The type of substance taken by the senior citizens, $28.57 \%$ take alcohol, $7.14 \%$ drugs, and $3.57 \%$ Bhang and $64.28 \%$ of the respondents this question is not applicable because they do not take any kind of substance.

The awareness about meal the senior citizens eat, $64.28 \%$ of the respondents said that they are full aware towards their meal, $21.42 \%$ average aware and rest $(14,28 \%)$ are less aware about their meal. Reaction towards safety measures used by the senior citizens, $71.42 \%$ said that they use helmets, $78.52 \%$ use seat belt, $28.57 \%$ Lathi and Stick and rest $17.85 \%$ use Knee Guards as safety measures when they go outside or when there are required. How senior citizens feel about their physical health, $42.85 \%$ said very good, $21.42 \%$ good, $17.85 \%$ average, $11.71 \%$ poor and rest $(7.14 \%)$ said that they feel very poor about their physical health. How senior citizens feel about their mental health, $46.42 \%$ said very good, $21.42 \%$ good, $17.85 \%$ average, $7.14 \%$ poor and rest $(7.14 \%)$ said that they feel very poor about their physical health. 


\section{SUMMARY \& CONCLUSION}

It is clear from the above interpretation that most of the senior citizens living in Radhey Green Colony of Dayalbagh Agra are of 60-65 years of age with intermediate and graduate education. Most of them belong to general caste category and living in joint family system and their marital status is married. The occupation they did or are doing for male government services and form females' housewife. The monthly personal income of the senior citizens is Rs. 10000-150000 and monthly family income is Rs. 20000-30000.

The life style of the senior citizens regardless to their economic status, caste and education variations they wake up at 4 O' clock early in the morning, do regular physical exercises and morning walk which are suitable, Meditation and Yoga. They go regular for health and physical examination to the doctor and physiotherapist as a routine checkup. Most of them do not consume any type of substance and alcohol. They are much aware about their meal and food habits and use safety measures when they go outside and use vehicles. Most of the senior citizens feel physically and mentally healthy and fit for and try to keep themselves in very good health condition.

Finally, the findings of the study show that senior citizens are health conscious. Their lifestyle, health behavior, attention on wellbeing, balancing diet, regular visiting to doctors and physiotherapists show their consciousness toward their health. They used to engage in health improving activities such as morning and evening walk, Yoga, Meditation and physical exercises and they used to safety measure behavior whenever they go outside from their house. Senior citizens kept away themselves from risking habits such as consuming substances and alcohol.

\section{References}

1. Babao, J.W. and Moscoso, L.S. (2008). Lifestyle and Health Status of Faculty of the College of Human Ecology and Food Sciences and the College of Education. Journal of the American Association, 16, 25-34

2. Banhato, E.F.C., Ribeiro, P.C.C, Guedes, D.V., Marmora, C.H.C. and Lourenco, R.A. (2015). Health Self Awareness in Senior Citizens: Focus on Physical, Emotional and Cognitive Health. Psychology, 6, 846-855. http://dx.doi.org/10.4236/psych.2015.67083

3. Basu, A. \& Dutta, M. J. (2006). The Relationship Between Health Information Seeking and Community Participation: The Role of Health Information Orientation and Efficiency. Health Communication, 23 (1), 79-79

4. Berry, J.W., Dalal, A. and Pande, N. (1994). Disability Attitude, Beliefs and Behavior: A Cross Cultural Study. Kingston: International Centre for Community- Based Rehabilitation.

5. Gesite, J. (2015). Health and Lifestyle Status of Senior Citizens in Northern Samar, Philippines. International Journal of Interdisciplinary Research and Innovations, 3 (2), 63-69

6. Gould, S.J. (1998). Consumer Attitude toward Health and Health Care: A Different Perspective. Journal of Consumer Affairs, 22 (1), 96-118

7. Hassen, A. \& Kibert, T.B. (2016). Health Related Behavior, Health Consciousness and Psychological Wellbeing among Teaching Faculty in Jimma University, Ethiopia. Clinical and Experimental Psychology. 2:113. doi:10.4172.cep.1000113

8. Iversen, A.C. \& Kraft, P. (2006). Does Socio-economic Status and Health Consciousness Influence. How Women Respond to Health Related Messages in Media? Health Education Research, 21 (6), 601-610

9. Karkal, M. (1999). Ageing and Women in India. Economic and Political Weekly, 34 (44), 54-56, Oct. 30, 1999. 
10. Kraft, F.B. \& Goodell, P.W. (1993). Identifying the Health Consciousness Consumer. Journal of Health Care Marketing, 13 (3), 18-25

11. Liba, A., Silva, H. \& Galhardoni, R. (2008). in Banhato, E.F.C., Ribeiro, P.C.C, Guedes, D.V., Marmora, C.H.C. and Lourenco, R.A. (2015). Health Self Awareness in Senior Citizens: Focus on Physical, Emotional and Cognitive Health. Psychology, 6, 846-855. http://dx.doi.org/10.4236/psych.2015.67083

12. Natsoulas, T. (1997b). Consciousness and self-awareness: Part II. Consciousness, Consciousness, and consciousness. Journal of Mind \& Behavior, 18 (1), 75-94.

13. Natsoulas, T. (1998). Consciousness and self-awareness. in M.D. Ferrari \& R.J. Sternberg, (Eds.), Self-awareness: Its Nature and Development. New York: The Guilford Press, 12-33.

14. Paterson, C. \& Feightner, J. (1997). Promoting the Health of Senior Citizens. Canadian Medical Association. 157 (8). 1107-1111, Oct. 15, 1997.

15. Shah, S.O. (2015). The Aged and the Aging: Profiles and Perspectives. Asian Journal of Research in Social Sciences and Humanities, 5 (8), Online. 12-15.

16. Shivramakrishnan, K. (2014). Aging and Dependency in Independent Indian Nation: Migrants Families, Workers and Social Experts (1940-60). Journal of Social History. 47 (4), 968-93.

17. World Health Organization (1978). Primary Health Care: Report of the International Conference at Alma Ata. Geneva: WHO.

18. World Health Organization (1988). Charter for Action to Achieve Health for All by the Year 2000 and Beyond. Geneva: WHO. 